\title{
The Role of Teachers in Value Education in High School Levels: A Survey of Success and Constraints
}

\author{
Godlif Sianipar \\ Faculty of Literature \\ Universitas Katolik Santo Thomas \\ Medan, Indonesia \\ godlif@yahoo.com
}

\begin{abstract}
This is a mixed method research. The purpose of this study is to identify the success and the constraints of value education at schools in the city of Medan. The respondents were taken randomly from the representatives of ten teachers from each public school, each religion-based private schools, and each national private school respectively. The results are that value education has been implemented in schools using the latest technologies, the updated materials in the classrooms and it is expected that the students absorb value education easily. Value education is also implemented at schools by applying the imitating method. The teachers through the nine roles of teachers become the role model in value education by imitating them. The success in value education can be measured by using the categories of the Moral Knowing, the Moral Perception and the Moral Action. The constraint of value education is mainly due to the unclear value of education materials from the government, and the need of the teachers for workshops or trainings on value education. This study recommends that value education needs to be regulated at school's academic calendar as a manifestation of a good will in implementing value education. Value education is important for the students as it will develop their inner capabilities.
\end{abstract}

Keywords-values; moral education; medan city; examples; teachers

\section{INTRODUCTION}

Global Culture [1], in one hand, has contributed to the phenomena of immorality, radicalism and corruptions in the modern society. The National Counter Terrorism Agency declared that 39 percent of the university students were exposed to terrorism. According to Anas Zaidi from the Indonesian Institute of Sciences, the influence of radicalism, in one hand, had dominated all major campuses in Indonesia [2]. On the other hand, value education in schools also experiences depreciation. As a result, many schools are overwhelming to handle bad habits of the students such as smoking, drugs using, violence, fighting, preteen alcohol drinking, and free sex. The question is whether the moral decadence phenomenon proves that the values of our society are shifting or not? Problems arise because the moral decadence phenomenon will risk the mission of education, namely "the transfer of values" and "the transfer of knowledge" [3]. Schools nowadays are facing the demand to take care of and pass on the humanity and universal values to the students but at the same time they must be able to face the secularized values.

Education is a process that will bring the students to maturation in every aspect of life [4] as school is a place to educate and at the same time a place for socializing [5]. In more specific, it is said that school is a place for the students to interact and certainly the interactions will involve a variety of values in the form of thoughts, speeches and deeds. There are values that are local to Indonesians such as politeness, tolerance, respect, honesty, responsibility, cooperation, and being faithful [6]. Similarly, there are also values that are equally important for the students in schools. The values are cultural transformation, personality formation, workforce preparation and preparation to become good citizens [7]. So, this is saying that the role of schools is not only a place to get knowledge, but also a place to develop the student's personality and capabilities.

However, in practice teachers during the teaching and the learning process in the classroom do not always integrate value education with the lessons they are teaching as they are focusing on transferring the knowledge alone to the students. Conceptually, the teacher's roles are as follows: informer, organizer, motivator, initiator, transmitter, director, facilitator, mediators, and evaluator [8]. By considering the variety of teacher's roles, value education should not be forgotten [9].

Value education, as a new joint movement program of the Indonesia Government, in its implementation has constraints. Handoyo [10], Alawiyah [11], and Ferreira and Schulze [12] summarize some constraints when value education are implemented in schools: (1) There is no technical implementations of value education, (2) Schools are not able to choose values in association with their vision and mission, (3) The teachers do not understand thoroughly about value education, (4) The teachers have difficulties in choosing values that appropriate to the lessons they teach, (5) The teachers feel incompetent in teaching value education, (6) The teachers have not become the role model of the values, (7) The teachers do not understand the concept of value education, (8) There is a gap between the makers of value education and the teacher's understanding of value education, (9) There is a lack of reflection on the values, (10) The teachers are not involved in implementing value education and the lack of training to teach value education, and (11) The teachers are not being 
practice when facing problems in implementing value education.

Schools as one of formal educational institutions are expected to play an important role in the implementation of value education in Indonesia. In the Manual of the National Character Development Policy in 2010-2025 [13] it is stated that the implementation of value education in schools is not only guiding the students' morally, but also as a whole promoting good habits (habituation), good understanding (cognitive), good feeling (affective) and eventually being able to practice them in daily life (psychomotor). Students are trained to see, to decide and to implement good habits (See, Judge and Act morally). Value education ultimately leads the students to carry out goodness constantly. This is what Lickona [14] suggests with moral knowing, moral feeling, and moral action in value education or in the terms of Ki Hajar Dewantara, the Founding Father of the National Education: "ngerti-ngerasa-ngelakoni" (understanding-realizing-doing). The high schools level in Medan is expected to have implemented value education.

The aim of the study is to survey the successes and the constraints of implementing value education in schools related to the nine teacher's roles; what kind of constraints that the teacher are facing when implementing value education; what success and unsuccess that the teachers have when they are promoting value education. Handoyo, Alawiyah, Ferreira and Schulze in the previous studies above studied the constraints of implementing value education in schools [10-12]. However, they did not study the success of implementing value education at schools so that teachers from different places could learn from the success. The typical survey has never been studied in the previous studies. The success in implementing value education in schools is also the success of the national character development. So, this is why the study is needed and for this reason, the study is entitled "The Role of Teachers in Value Education in High School Levels: A Survey of Success and Constraints". The research questions of the study are: (1) What are the constraints of value education in schools in Medan? (2) What are the success and the unsuccessful of value education in Medan?

\section{METHOD}

The method of the study is Mixed Methods in nature as the study aimed gaining the trend the success and the constraints of implementing value education among the high school levels in the city of Medan. The researcher therefore identified phenomenology as an appropriate research design for the study [15] and used questionnaires, and several open-ended questions for the purpose.

The subject of the study was teachers at high school levels in the city of Medan. The respondents of the study were 1972 teachers which were chosen randomly from the representatives of ten teachers of each school. The researcher categorized the schools into three categories: public schools $(n=21)$, faithbased private schools $(\mathrm{n}=111)$, and national private schools $(n=186)$. Respondents from Catholicism were 25 percent $(n=493)$, Protestants 37 percent $(n=727)$, Islam 36 percent $(n=718)$, Buddhists 1.4 percent $(n=27)$, Hindus 0.2 percent $(n=4)$ and others 0.2 percent $(n=3)$. More than half $(58.6$ percent) of the respondents were women $(n=156)$ and men 41.1 percent $(n=811)$.

The instrument of collecting the quantitative data were using questionnaire. The questionnaire is divided into nine group of questions based on the nine teacher's roles. Each item is equipped with four answers on the Likert scales. The qualitative data is collected along with the questionnaires [16]. There were three open-ended questions which the respondents were asked to answer. The questions were about the success, the constraints, and the factors that prohibited the teachers in implementing value education respectively. These types of instrument in collecting the data are cheap and faster. The researcher certainly has experience in using the Mixed Method [17].

In terms of the data analysis, the validity of the quantitative data were sought by using the product moment correlation from Pearson [18]. The SPSS version 21 program were used to analyze the frequency of how many respondents chose answer in each category of the teacher's roles; the correlation between each item. The Factor Analysis were used to manage the quantitative data by clumping them into groups or factors [19]. The qualitative data were analyzed by segmenting the data into meaningful analytical units. The significant segments of the data were identified by means of the three themes in the open-ended questions.

\section{RESULTS AND DISCUSSION}

\section{A. The Respondent' Perceptions on the Teacher's Roles}

1) Teacher as Informer



Fig. 1. The role of teacher as informer

Teacher as informer means that teacher is an informative person, a laboratory officer, a field study assistant and a source of information on academic and general activities. The researcher asked five items on this topic: (A1) The lesson information will improve the character of the student, (A2) Experiencing difficulties due to the lack of understanding on value education, (A3) The information technologies barriers to value education, (A4) Reading books forming the students' characters, and (A5) Ever giving directly information about values. As a result, Fig. 1 shows that more than half of the respondents agree that teachers and reading books help the students improving their character. Almost half of the respondents agree that there are two barriers when they carry out their role as informer, namely the lack of understanding on 
the meaning of value education and the abusive use of information technology among the students.

\section{2) Teacher as Organizer}

Teacher as organizer means that the teacher organizes the components of academic activities to achieve effectiveness and efficiency in the teaching and learning process. The teachers make planning, workshops, the classroom schedules and others. The researcher conveys five items related to the topic: (B1) The student council can teach them discipline and respecting others, (B2) The school leaders do not plan the character building programs, (B3) The school has programs on social services, (B4) Extracurricular can shape the student character, and (B5) The spiritual activities develop the student character. Regarding the teacher's role as organizer, more than half of the respondents agree that the student council, extracurricular and spiritual activities in schools help the students in value education. For this reason, schools have to make a regular schedule for value education as more than half of the respondents agree that their schools do not have a regular schedule for value education.

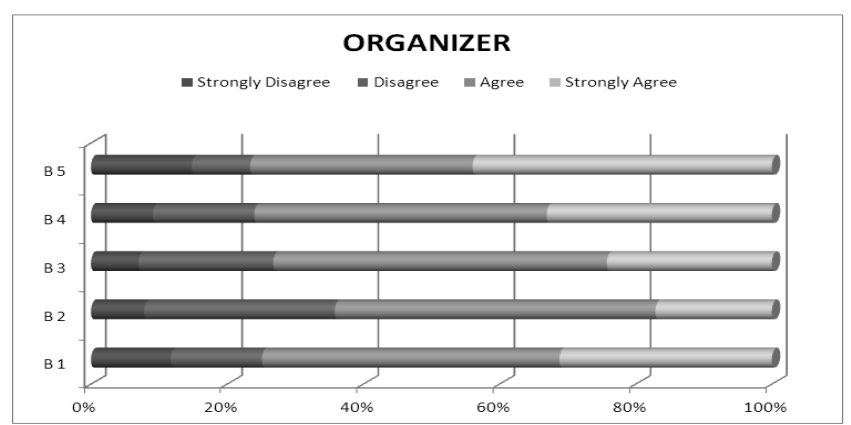

Fig. 2. The role of teacher as organizer

\section{3) Teacher as Motivator}

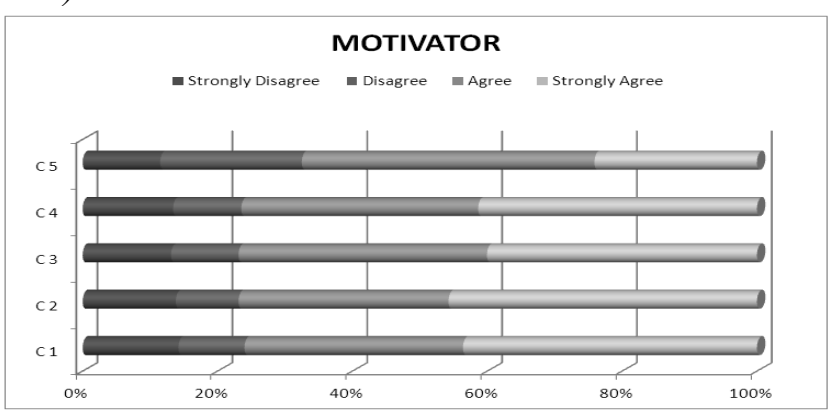

Fig. 3. The role of teacher as motivator

Next is the respondent's perception of the teacher's role as motivator. Teacher as motivator means that the teacher has a role to put more dynamic and development on the teaching and the learning process. Teachers help the students by providing stimulations, encouragements and reinforcements so that the students' potentiality and creativity grows which will affect the dynamics in the learning process. The researcher conveys five items related to the topic: (C1) Directing the students to be kind to others, (C2) Examples, (C3) The students are asked to be in order before the lesson begins, (C4) Motivating the students to have good achievements and have a good character, and (C5) Having difficulties to understand the contents of value education from the government. In this part most of the respondents agree that the students must be motivated to do good, be orderly in the the classroom and have achievements. As motivator, the teachers' examples are needed. However, most of the respondents agree that they have difficulties in understanding the value of education of the government.

\section{4) Teacher as Initiator}

The meaning of teacher as initiator is that the teacher triggers ideas in the learning process. The ideas should be creative that the students can mimic. The researcher ask five items related to the topic: (D1) Each class begins and ends with prayer, (D2) Value education is taught innovatively and creatively, (D3) The event of seminars on the development and the progress of value education are held, (D4) The value education handbook of the government is not good, and (D5) Recognizing the inner potentials the students have and training them to actualize them. More than half of the respondents agree that the teachers' role as initiator can be value education to the students. Value education is when start and end the class with prayer. In addition, an innovative and creative learning process is needed so that value education can be more meaningful. Teachers need to recognize the inner potential of the students to be actualized. The value education books of the government constraints the development of the teacher's role as initiator.

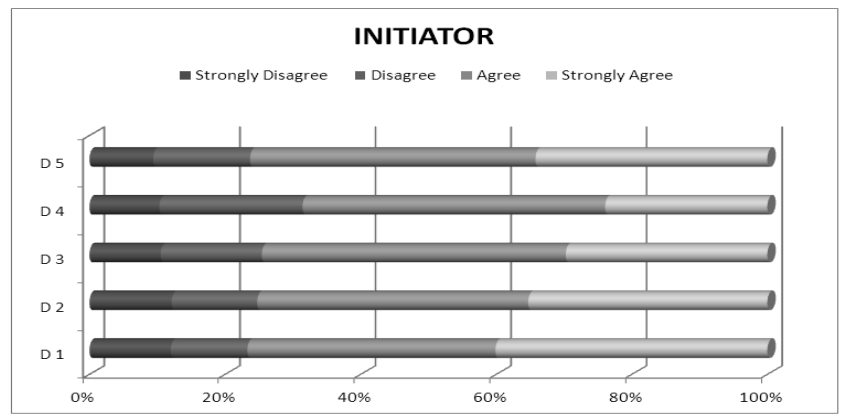

Fig. 4. The role of teacher as initiator

\section{5) Teacher as Transmitter}

The role of teacher as transmitter is that the teacher acts as a disseminator of the education policies and the knowledge. To explore the respondents' understanding of the teacher's roles as transmitter, the researcher ask five items related to the topic: (E1) Value education must be delivered, (E2) the students do not understand value education just as the teacher, (E3) Value education is implemented along with the students beliefs, (E4) Teachers must be responsive to develop value education, and (E5) Teachers practice time discipline. In this part, more than half of the respondents agree that the value education must be delivered to the students until they understand the meaning of the values. So, strategies are needed in promoting value education. The disciplined and the responsive teachers are needed. 


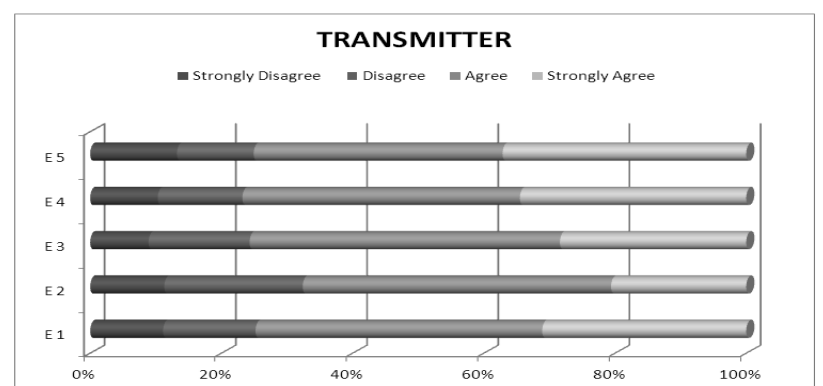

Fig. 5. The role of teacher as transmitter.

\section{6) Teacher as Director}

The meaning of the teacher's roles as director is that the teacher guides and directs the learning activities in the classroom in accordance with the stated goals. The researcher ask five items in related to the topic: (F1) Teachers do not state the needed value education, (F2) Teachers feel no obligatory to direct value education as they are not ready, (F3) Teachers explain the connection between the lesson with daily life, (F4) Teachers guide the students to conclude the lesson, and (F5) Teachers ask the students to search for the learning materials. In the teaching and the learning process, more than half of the respondents agree that the teacher's role as director is to make the students independent and be self-confident. The goal can only be achieved when the teacher links the lesson with daily life. However, more than half of the respondents experience difficulties to deliver value education as they are not ready to deliver them.

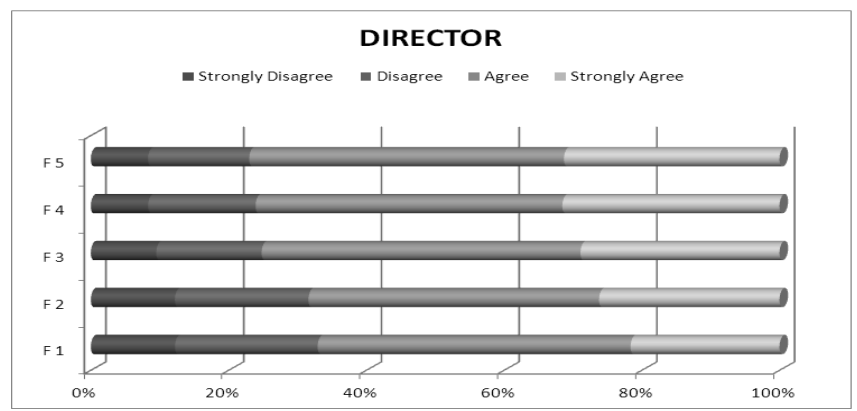

Fig. 6. The role of teacher as director

\section{7) Teacher as Facilitator}

The teacher's role as facilitator means that the teacher is obliged to facilitate easiness in the teaching and the learning process, so that the teaching and the learning interactions take place effectively and optimally. The researcher ask five items related to the topics: (G1) The use of audio-visual in the classroom, (G2) A creative learning process as the transformation of value education, (G3) Lack of understanding on how value education is implemented, (G4) Understanding different types of learning media to build the students' character, and (G5) Value education is shown through the teacher's example. In this part, more than half of the respondents agree that audio-visual and being creative in the classroom is helpful in value education. The teacher's examples are needed in value education. The constraint is that more than half of the respondent lack of understanding on value education is applied.

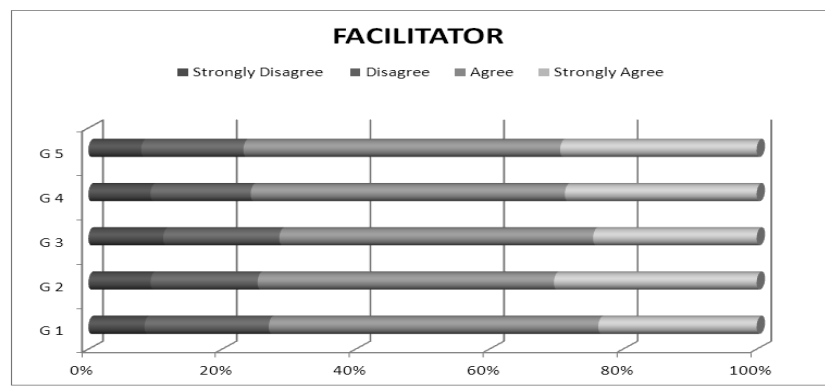

Fig. 7. The Role of Teacher as Facilitator

\section{8) Teacher as Mediator}

Teacher as mediator means that the teacher acts as an intermediary in the student learning activities. For example, giving solution when the students' discussion is deadlock. Being mediator can also be interpreted as providers of learning media. Teachers decide which learning media is appropriate to be used in the classroom. The researcher ask five items related to the topic: (H1) Using the technology media in value education, (H2) Never participating in value education's workshops, (H3) Each learning media could help value education, (H4) The use of media is needed accordingly to value education, and (H5) Problems in implementing value education can be solved. More than half of the respondents agree on the importance of using technologies in the learning process. Teachers can choose the right media to promote value education. In addition, more than half of the respondents agree that workshops are needed to train the teachers about value education.

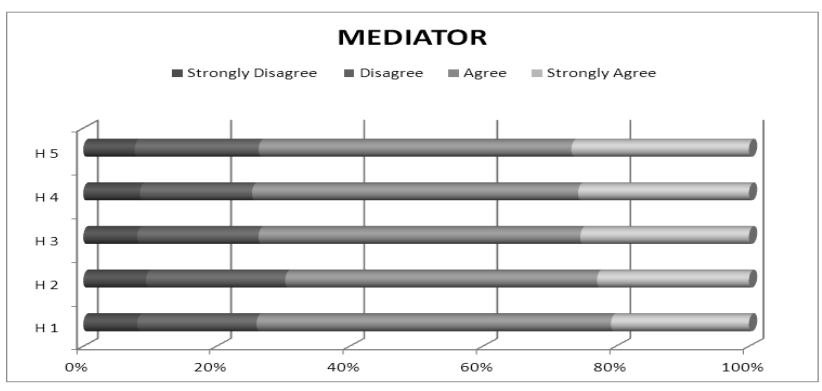

Fig. 8. The role of teacher as mediator

\section{9) Teacher as Evaluator}

The meaning of the teacher's role as evaluator is that the teacher has the task of assessing and observing the students' development in the learning achievement objectively. Evaluation is made with the standardized methods. The researcher ask five items related to the topic: (I1) Difficulties in determining the values to be achieved, (I2) Difficulties in measuring the students' grades, (I3) There are clear instructions in implementing value education, (I4) There are tools to evaluate value education; and (I5) Personal duty to establish good values. As evaluator, half of the respondents agree in determining the values to be achieved and the measurements to be used in value education. In addition, the evaluations, instructions and the individual task are needed in value education. 


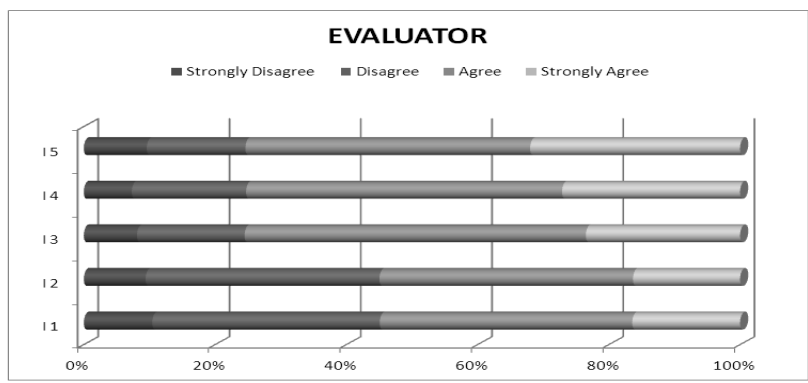

Fig. 9. The role of teacher as evaluator

\section{B. Factor Analysis}

To find out the constraints and the success of value education, the 45 items were subjected to principal component analysis (PCA) using SPSS Version 21. Inspection of the matrix correlation revealed the presence of many coefficients of 0.3 and above. The Kaiser-Meyer-Oklin (KMO) value was 0.98 , exceeding the recommended value of 0.6 and Bartlett's Test of Sphericity reached statistical significance, supporting the factorability of the correlation matrix.

TABLE I. PATTERN AND STRUCTURE MATRIX FOR PCA WITH OBLIMIN ROTATION OF TWO FACTOR SOLUTION OF THE TEACHER ROLES

\begin{tabular}{cccccccc}
\hline Items & $\begin{array}{c}\text { Pattern / Structure } \\
\text { Coefficients }\end{array}$ & Comm. Items & \multicolumn{2}{c}{$\begin{array}{c}\text { Pattern / Structure } \\
\text { Coefficients }\end{array}$} & Comm. \\
\hline & 1 & 2 & & & 1 & 2 \\
A 1 & $.842 / .832$ & & .696 & E 3 & $.776 / .784$ & .618 \\
A 2 & & $.718 / .711$ & .507 & E 4 & $.868 / .864$ & .747 \\
A 3 & & $.563 / .558$ & .312 & E 5 & $.821 / .815$ & .666 \\
A 4 & $.731 / .748$ & & .570 & F 1 & & $.750 / .741$ & .552 \\
A 5 & $.852 / .846$ & & .717 & F 2 & & $.731 / .706$ & .522 \\
B 1 & $.830 / .831$ & & .690 & F 3 & $.792 / .791$ & & .626 \\
B 2 & & $.560 / .595$ & .403 & F 4 & $.816 / .818$ & & .669 \\
B 3 & $.707 / .719$ & & .523 & F 5 & $.766 / .779$ & & .614 \\
B 4 & $.810 / .808$ & & .654 & G 1 & $.765 / .774$ & & .602 \\
B 5 & $.883 / .873$ & & .766 & G 2 & $.836 / .833$ & .695 \\
C 1 & $.895 / .880$ & & .783 & G 3 & & $.558 / .608$ & .473 \\
C 2 & $.901 / .889$ & & .796 & G 4 & $.832 / .839$ & & .706 \\
C 3 & $.886 / .872$ & & .768 & G 5 & $.828 / .828$ & & .686 \\
C 4 & $.879 / .867$ & & .758 & H 1 & $.660 / .676$ & & .468 \\
C 5 & & $.761 / .758$ & .575 & H 2 & & $.730 / .738$ & .548 \\
D 1 & $.855 / .842$ & & .716 & H 3 & $.708 / .721$ & & .527 \\
D 2 & $.879 / .871$ & & .761 & H 4 & $.807 / .816$ & & .669 \\
D 3 & $.798 / .800$ & & .640 & H 5 & $.762 / .772$ & & .600 \\
D 4 & & $.676 / .698$ & .506 & I 1 & & $.650 / .635$ & .413 \\
D 5 & $.842 / .838$ & & .703 & I 2 & & $.615 / .612$ & .375 \\
E 1 & $.842 / .829$ & & .694 & I 3 & $.771 / .774$ & & .599 \\
E 2 & & $.748 / .747$ & .558 & I 4 & $.801 / .804$ & & .648 \\
& & & & I 5 & $.841 / .837$ & .702 \\
\hline & & & & & & & \\
\hline
\end{tabular}

PCA components analysis revealed the presence of two components with eigenvalues value exceeding $1,49.8 \%$ and $12 \%$ of the variance respectively. The two-component explained a total of $61.8 \%$ of the variance. Using Catell's scree test, it was decided to retain two components for further investigation. To aid in the interpretation of these two components, oblimin rotation was performed. The rotated solution revealed the presence of simple structure with both components showing a number of strong loadings and all variables loading substantially on only one component. The interpretation of the two components was consistent where items about the success of value education loading strongly on Component 1 and items about the constraints in value education on Component 2. There was a weak correlation between the two factors $(\mathrm{r}=0.16)$.

\section{CONCLUSION}

In conclusion, the study found that: (1) Most of the teachers have implemented value education in schools as value education is important for the students, (2) Value education has been implemented in schools using the latest technology so that updated value education material is given to the students, (3) Value education is also implemented in schools by the teacher examples as the role model in value education. (4) The success in value education can be measured using the categories of Moral Knowing, Moral Perception and Moral Action. Value education needs to be regulated in the school's academic calendar as a manifestation of a good will implementing value education. The students need value education as it will develop the inner potentials.

The recommendations of the study are as follows: (1) Value education requires continuing efforts. So, it is necessary to have a sustainable study on value education to help the stakeholders to anticipate the problems in value education. (2) The study is carried out in the city of Medan, where the population is plural. For further research, it is necessary to study value education in a homogeneous society as a comparison.

\section{ACKNOWLEDGMENT}

The research is made possible by the financial support of the Research Institution of the Universitas Katolik Santo Thomas, Medan. I would like to thank the university for supporting me to do the research. My gratitute goes to the chair of the research institute for some insights to the research as well.

\section{REFERENCES}

[1] R. Robertson, Globalization: Social Theory and Global Culture. London: Sage Publications Ltd., 2000.

[2] F. Gufron, "Selamatkan Mahasiswa Dari jebakan Radikalisme," Kompas Daily, Jakarta, p. 4, 24-Feb-2018.

[3] D. Suryadi, "Membangun Kemandirian Berpikir Pendidik Melalui Penelitian Pembelajaran," Bandung, 2015.

[4] N. Azizah, "Perilaku Moral dan Riligiusitas Siswa Berlatar Belakang Pendidikan Umum dan Agama," J. Psikol., vol. 33, no. 2, pp. 1-16, 2006.

[5] B. S. Furhmann, Adolescence. London: Scott, Foreman and Company, 1990.

[6] Fathurrohman, "Implementasi Pendidikan Nilai Dalam Proses Pembelajaran di SD Muhammadiyah 3," Universitas Negeri Yogyakarta, 2014.

[7] G. Sianipar and A. C. Nainggolan, "Pendidikan Nilai oleh Guru Sekolah Berbasis Agama," in Pengembangan Teknologi dan Sumber Daya Manusia Hebat yang Bermentalitas Unggul, 2017, pp. 52-71.

[8] Sardiman, Interaksi dan Motivasi Belajar Mengajar. Surabaya: Rajawali Pers, 2009.

[9] N. Azizah, "Perilaku Moral dan Religiusitas Siswa Berlatar Belakang Pendidikan Umum dan Agama," J. Psikol., vol. 33, no. 2, pp. 94-109, 2006.

[10] B. Handoyo, "Kendala-Kendala Implementasi Pendidikan Karakter di Sekolah," $2012 . \quad$ [Online]. Available: 
https:/hangeo.wordpress.com/2012/03/15/kendala-kendalaimplementasi-pendidikan-karakter-di-sekolah/. [Accessed: 24-Feb2018].

[11] F. Alawiyah, "Kebijakan dan Pengembangan Pembangunan Karakter Melalui Pendidikan di Indonesia," Aspirasi, vol. 3, no. 1, pp. 87-101, 2012.

[12] C. Ferreira and S. Schulze, "Teachers' Experience of the Implementation of Values in Education in Schools: 'Mind the Gap,"' South African J. Educ., vol. 34, no. 1, pp. 1-13, 2014.

[13] Pemerintah R.I., Kebijakan Nasional Pembangunan Karakter Bangsa Tahun 2010-2025. Jakarta, 2010.

[14] T. Lickona, "Character Development in the Family," in Character Development in Schools and Beyond, K. Ryan and G. F. McLean, Eds. New York: Praeger, 1991, pp. 253-273.

[15] L. M. Given, The SAGE Encyclopedia of Qualitative Research Methods. CA: Sage Publications Ltd., 2008.

[16] E. Babbie, The Practice of Social Research. Belmont, CA: Thomas Learning, 2000.

[17] J. W. Creswell, Research Design: Qualitative, Quantitative and Mixed Method Approaches. Thousand Oaks, CA: Sage Publications Ltd., 2000.

[18] S. Arikunto, Dasar-Dasar Evaluasi Pendidikan. Jakarta: Bumi Aksara 2009.

[19] J. Pallant, SPSS Survival Manual, 3rd ed. New York: Open University Press, 2007. 